\title{
電圧式人体通信とウェアラブル・ガジェット
}

\author{
加藤 康男 $*$
}

\section{Wearable Gadget with Intra-Body Communication Technology}

\author{
Yaso KATO*
}

* 青山学院大学理工学部（率 252-5258 神奈川県相模原市中央区淵野辺 5-10-1）

* Department of Science and Engineering, Aoyama Gakuin University (5-10-1 Fuchinobe, Chuo-ku, Sagamihara-shi, Kanagawa 252-5258)

\section{1. はじめに}

近年流行しているウェアラブル (Wearable) 指向にマッチ する通信技術として, 利用者の身体を伝送線路として活用 する「人体通信技術」が注目を集めている。そもそも人体 通信は, 1995 年にアメリカのマサチューセッツ工科大学 (MIT) メディアラボの大学院生であった T. G. Zimmerman ら によって提案された近距離通信技術で ${ }^{1)}$, 当初はウェアラ ブル・コンピュータの機器間接続の新技術として考案され たと言われている。日本では 1997 年に, NTT ヒューマン インターフェース研究所（当時）の福本雅朗博士（現 Microsoft Research Asia）の研究発表が，日本における最初 の本格的な人体通信研究であったと考えられる ${ }^{2}$ 。

一方，1996 年に電界強度から電気信号を計測する特殊な

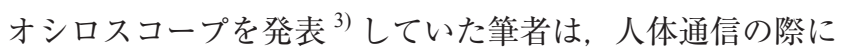
人体から染み出す電界計測手段を模索していた福本博士と 知り合い, 縁あって 2000 年から人体通信技術の研究に携わ ることとなった。

コンピュータやセンサ, 通信端末などを利用者の身体に 装着して使用する人体通信技術の特殊性から, 日本では主 に医療やセキュリティへの適用が検討されて来たが, 残念 ながら現状まで普及は進んでいない。その原因だが, 電気 や光の通信ケーブルが無いため, 研究者や開発技術者が無 線通信と混同してしまい, 従来の無線技術と同じ思想で開 発を進めて失敗を重ね, 遂には時間切れや開発費枯渇によ り開発中止に追い达まれる, というパターンが多いようで ある。また，正しく動作する人体通信ガジェットの開発が 困難であるため, 実験に裏打ちされた正しい知見を得られ ず，電磁界シミュレーションを用いた表面的なアプローチ から抜け出せないケースも散見される。

特定の研究者やグループに対してのアドバイスという訳 ではないが, 本当に人体通信技術の研究や普及を促進した いのであれば,「人体通信技術＝従来の無線技術」であるこ とを研究者自身がよく理解し, 電磁界シミュレーションゃ 机上の論理はとは別に, 実際に動作する人体通信ガジェッ
卜を開発する努力を重ねた上で研究を進めることが最も大 切であることを伝えたい。

本稿では，筆者の約 14 年余に渡る研究から得た知見と， これまでに発表した学術論文に立脚して, 電圧式人体通信 技術の解説を展開するとともに，筆者が開発した最新の人 体通信ガジェットを紹介する。

\section{2. 電圧式人体通信}

\section{1 電圧式人体通信研究の歴史}

筆者の人体通信技術の研究経験と, その過程で得た知見 と見聞にもとづいて作成した電圧式人体通信技術に関する 年表を Fig. 1 に示す。前章でも述べたように，研究のス タートはアメリカMITである。その後, NTT ヒューマンイ ンターフェース研究所 (当時) から NTT ドコモマルチメ ディア研究所（当時）を経て，一旦はNTT 厚木 R\&D セン ターに開発主体が移ったが ${ }^{4}$, 開発方針の相違からその後 さらに開発チームが枝分かれした。

筆者は, 2003 年から NTT ドコモ総合研究所（当時）と 共同で研究を進め, 2004 年〜2006 年までは東京医科歯科大 に在籍しつつ, 人体通信の医療分野への応用について研究 も進めた ${ }^{5)}$ 。途中, 2005 年には東京都立産業技術研究所の お招きを受け，日本で最初に人体通信技術の講演をさせて 頂いた ${ }^{6}$ 。その後, 2007 年の CEATEC においては, 世界初 となる人体通信技術を搭載した端末電話の出展を実現し た ${ }^{7)}$ 。このCEATEC 2007 における発表や, その時期の新聞 やテレビ報道によって，それまではNTT とドコモの関係者 しか知らなかった人体通信技術が，広く一般に知られるこ ととなった。Fig. 1 から，2007 年頃を境に新たに人体通信 の研究に興味を持つ企業や大学が増えたことがわかる。な お，Fig. 1 については，人体通信技術の萌芽期にフォーカ スしているため, 2010 年頃までに人体通信技術に関する学 術論文を発表している個人や企業を研究者と定義して記載 しており，それ以降に研究を始めた研究者や学術論文を発 表していない個人または企業については記載の対象として いない。余談になるが, CEATEC 2007 の会場で初めて名刺 


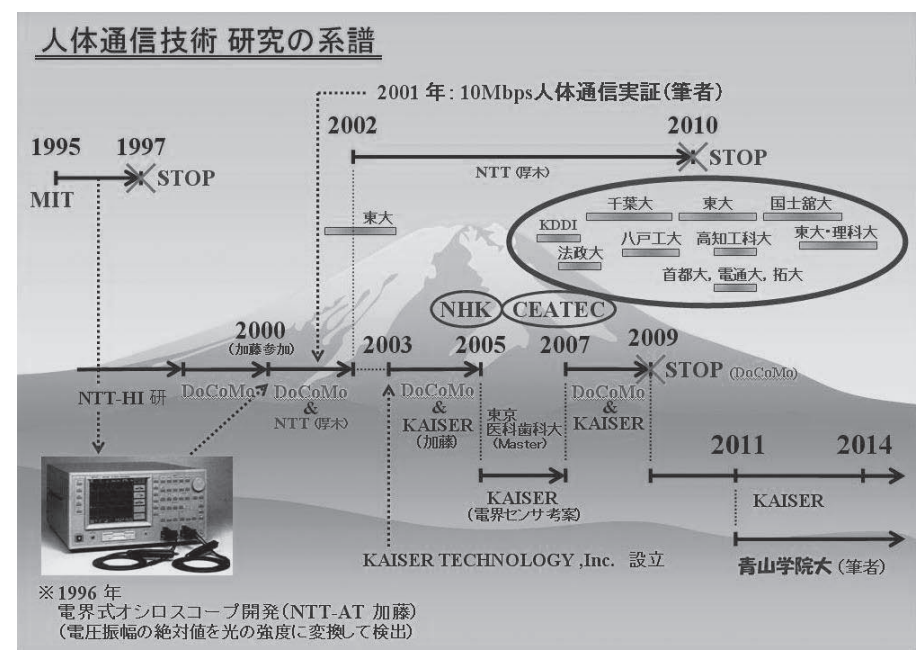

Fig. 1 The history of intra-body communication technology in Japan

を頂いた方が翌日から「人体通信に詳しい」との触れ込み で各種メディアの取材を受け，知らないはずの人体通信に ついてコメントしていたのには筆者㧍よび関係者一同が驚 いたが，何としてもコメントしたいほどにインパクトのあ る技術であると感じて頂けたことは，文字通り開発者冥利 に尽きるエピソードである。

NTT ドコモ総合研究所（当時）は 2009 年頃, NTT 厚木 R\&D センターは 2010 年頃にそれぞれ研究を終えている。

\section{2 電圧式人体通信の概略}

Fig. 2 に示すのが, 人体通信の原点とも言える, 人体通 信式ウェアラブル・コンピュータの実現を目標とした“非 接地型電圧式人体通信”の概念図である ${ }^{8)}$ 。

人体は，低周波 $10 \mathrm{MHz}$ 程度の周波数領域においては 導体とみなしてよく ${ }^{8)}$, また，人体通信の送受信電極は絶 縁皮膜で覆われていることから，電極を皮虐に密着させた 場合であっても電極と人体は容量性の結合となる。した がって，人体の任意の箇所に送信機と受信機を装着するこ とで以下のような通信が可能となる。

[送信電極 $] \rightarrow$ 容量結合 $\rightarrow[$ 人体 $] \rightarrow$ 容量結合 $\rightarrow[$ 受信電極 $]$

このとき，利用者の身体に装着した送信機 (Tx) から送信 電極を介して利用者自身の身体に対して，通信デー夕に基 づいて生成される交流電圧（最小 $300 \mathrm{mVpp}$ 程度）を印加 すると，利用者の身体表面から染み出すように信号電界が 発生する。この電界は, 通信デー夕を含む近傍界の電界で あり，発生源たる人体から空間に伝搬する距離に応じて急 激に強度が減衰する特性を持つ。したがって, 通信デー夕 は人体表面付近に留まり，遠方には到達することがない。 また，通信の際に搬送波として用いる交流信号の周波数が 低い（波長が長い）ほど，人体から空間に染み出す割合が 少なくなることが分かっている ${ }^{6}$ ため，搬送波周波数が低 いほど通信の秘匿性は高くなる。このように，人体通信は 従来の無線通信とは異なり，電波（放射電磁界）を使わな いことから，空間に電波を放射させる必要はなく，通信時

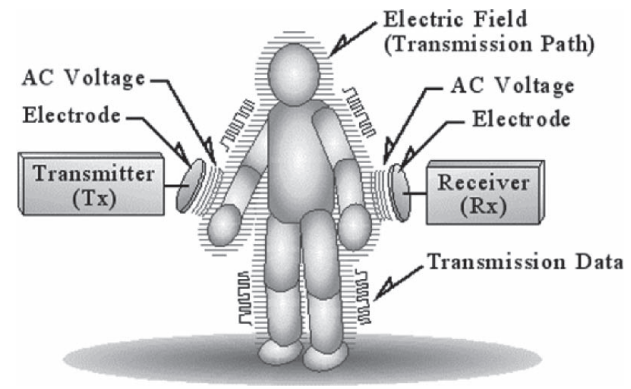

Fig. 2 Concept of wearable type intra-body communication

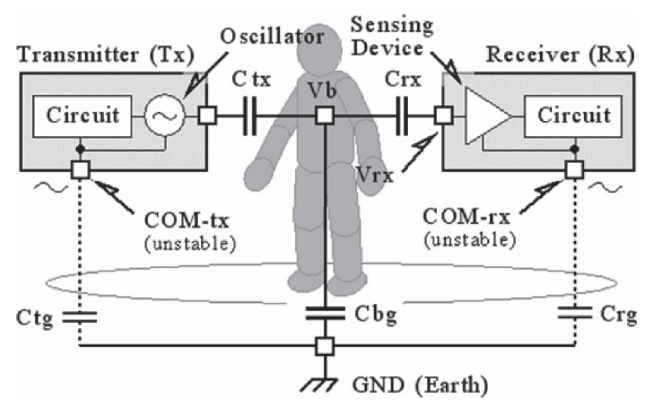

Fig. 3 Equivalent circuit of the non grounding type intrabody communication

の消費電力を低く抑えられる。また，送信用アンテナも不 要になることから，通信装置の小型軽量化を図ることがで きる。

\section{3 電圧式人体通信の分類}

\subsection{1 非接地型人体通信}

前項で述べたように，電圧式人体通信は静電容量結合に よる情報伝達系であることから，Fig. 2 は Fig. 3 のように表 わされる。これが, ウェアラブル型電圧式人体通信の電気 的等価回路となる ${ }^{8)}$ 。なお，以後の全ての回路図において， 点線部分は空間を介した静電容量的な接続を意味し，実際 にはケーブルは存在しないものとする。

Fig. 3 に抢いて, Ctx は送信機 $(\mathrm{Tx})$ の電極と人体間の静 
電容量を表わしており，Crx は受信機 $(\mathrm{Rx})$ の電極と人体間 の静電容量を表わしている。また, Cbg は人体と大地グラ ンド GND (Earth) 間の静電容量を表わしている。人体表面 の電界強度は電圧 $V b$ で表わされるものとし, 電界センシ ング素子 (Sensing Device)への入力電圧をV $V r x$ で表わす。こ のとき, 送信機 $(\mathrm{Tx})$ と受信機 $(\mathrm{Rx})$ の回路グランドに相当 する COM-tx と COM-rx は, それぞれ Ctg と Crgによって 直流的に GND (Earth) と分離され, 不安定な状態 (unstable) となっている。このように, COM-tx $\neq$ GND (Earth), COM-rx $\neq$ GND (Earth), COM-tx $\neq$ COM-rx が同時に成り立 つ場合を「無接地型 (Non Grounding Type)」と呼ぶ。すなわ ち, ウェアラブル対応型人体通信は「非接地型」人体通信 を意味している。

ここで, 各ノードの電圧変動が理解し易いように, Fig. 3 をインピーダンス表示に変換して Fig. 4 とする。Ctx と Crx は, 電極と人体間のインピーダンス Ztx と Z r r に変換され, Cbg は人体と GND (Earth) 間のインピーダンス Zbg に変換 される。また, 人体から発生する電界強度は電圧 $V b$ で, センシング素子入力電圧はV $V r x$ でそれぞれ表わされる。Ztg や $\operatorname{Zrg}$ は, 条件によっては数百 $\mathrm{k} \Omega$ 以上の值となり, 送信 機 (Tx) や受信機 (Rx) と GND (Earth) との位置関倸によって 決まるため, 利用者の動作に伴って頻繁に変動し, その変 動幅も大きい。この不規則なインピーダンス変動が, 非接 地型人体通信の安定度を損なう最大の原因となる。

\subsection{2 部分接地型人体通信}

これまでに最も多く発表されているのが「部分接地型 (Partial-grounding Type)」人体通信技術である ${ }^{8)}$ 。これは,

Fig. 5 のように, カード型送信機 (Tx) を首から提げて携行 し, 受信機 $(\mathrm{Rx})$ に接続された床電極 (Rx Electrode) の上に 立つと送信データが人体を経由して床電極に伝わり, 自動 ドアが開くようなアプリケーションとして示されることが 多い。

また, Fig. 5 のシステムは Fig. 6のインピーダンス等価回 路で表わされる。Ztx は送信機 $(\mathrm{Tx})$ の電極と人体間のイン ピーダンス, $\operatorname{Zrx}$ は受信機 $(\mathrm{Rx})$ の電極と人体間のインピー ダンスを表わしている。また, Fig. 6 は, Fig. 4 の Zrg を取 り除いて GND (Earth) に接続した回路と等価になる。Zrgを

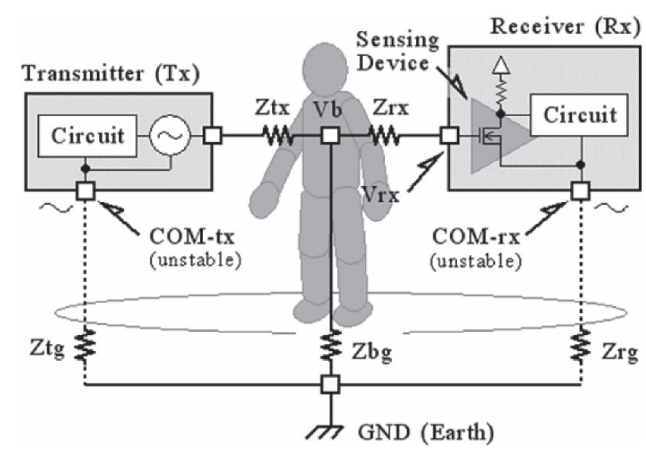

Fig. 4 Impedance equivalent circuit of Fig. 3
取り除くとは，受信機 $(\mathrm{Rx})$ の電子回路グランド (COM-rx) を GND (Earth) に接続することを意味する。具体的には受 信機 $(\mathrm{Rx})$ の電源を商用電源 $(\mathrm{AC} 100 \mathrm{~V})$ から供給すればよ い。この場合, COM-rx の電位が安定することから, 特殊 な電界センシング素子が不要になり, 技術開発の難度は格 段に下がる。ただし，この場合にも送信機 (Tx) は身に付け て使用することから，Ztgの不安定要素は依然として残る が, 送信機 $(\mathrm{Tx})$ の出力電圧を高くするなどの “力技” で対 応することが可能となる。

しかし, 送信機 (Tx) の出力電圧を高くすることは消費電 力と電池容量の増大を伴うことから, 実用化の際には十分 な検討が必要となる。

この「部分接地型人体通信」は「非接地型人体通信」の 次に難度の高い電圧式人体通信技術である。

\subsection{3 完全接地型人体通信}

最後に「両接地型 (Full-grounding Type)」について述べ る。これは文字通り, 送信機 $(\mathrm{Tx})$ と受信機 $(\mathrm{Rx})$ の両方を 接地して使う人体通信技術である ${ }^{8)}$ 。両接地型人体通信の 装置は, Fig. 7 に示すように, 送信機 $(\mathrm{Tx})$ と受信機 $(\mathrm{Rx})$ の 両方が商用電源に接続されることから, 装置を身に着けて 使用することができない。送信機 $(\mathrm{Tx})$ と受信機 $(\mathrm{Rx})$ の両 方を携行できない人体通信の用途は極めて限定されるが, 原理デモ機や据え置き型のゲーム機器などへの応用は可能 である。また，電気的には Fig. 8 のインピーダンス等価回 路で表わされる。このとき, $Z t x$ は送信機 $(\mathrm{Tx})$ の電極と人

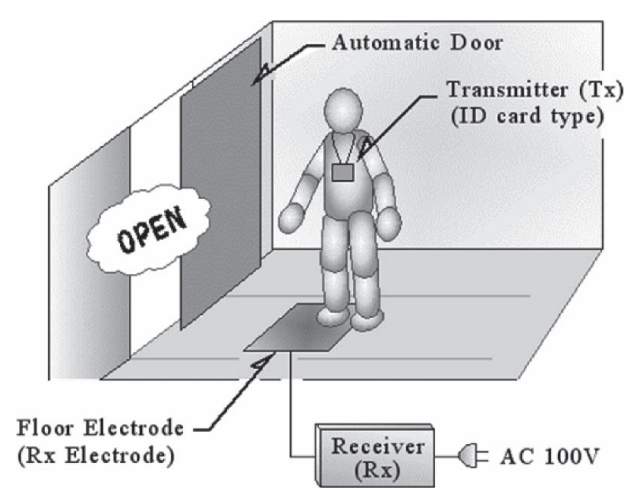

Fig. 5 Example of one-side grounding type intra-body communication

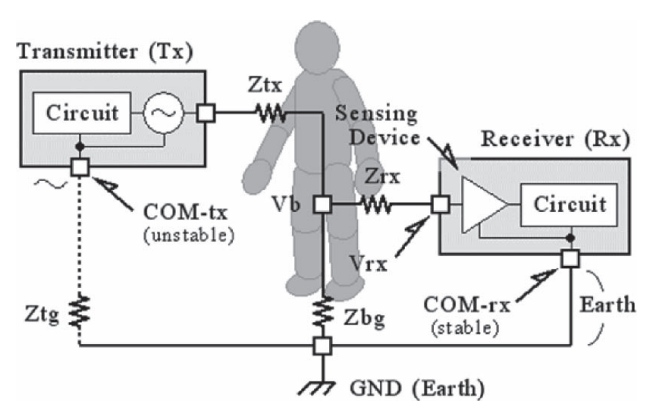

Fig. 6 Impedance equivalent circuit of Fig. 5 
体間のインピーダンス, $Z r x$ は受信機 $(\mathrm{Rx})$ の電極と人体間 のインピーダンスを表わしている。この回路は, Fig. 6 か ら Ztg を取り除くことで実現できる。Ztgを取り除くとは, 送信機 (Tx) の回路グランド (COM-tx) を大地グランド GND (Earth) に接続することを意味し，具体的には送信機 (Tx) の 電源を商用電源から供給すればよい。この理由は部分接地 型の場合と同じである。もの珍しさも手伝って, 時折報道 などで取り上げられることがあるが，この技術をウェアラ ブル用途に応用することは難しい。

なお，両接地型人体通信には技術的に難しい要素が少な く，人体通信技術について詳しい知識を持っていなくても 比較的簡単に装置を構成できる。

\subsection{4 電圧式人体通信の技術難度}

電圧式人体通信技術の難度と応用分野の概略を Fig. 9 に

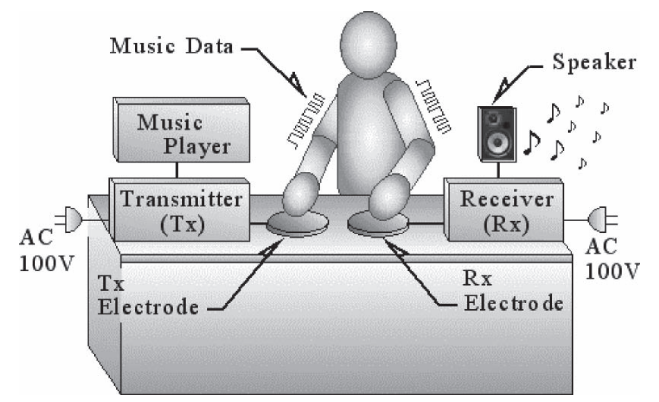

Fig. 7 Example of both grounding type intra-body communication

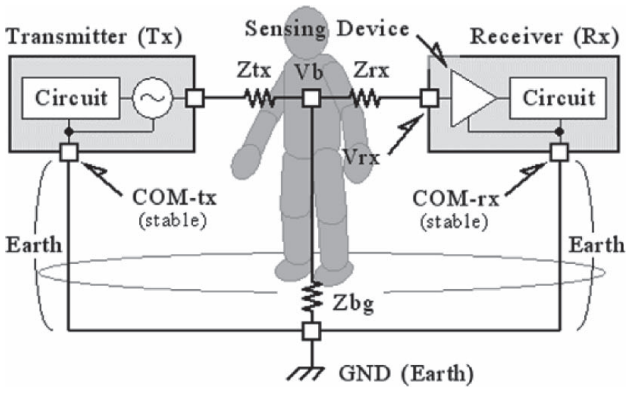

Fig. 8 Impedance equivalent circuit of Fig. 7

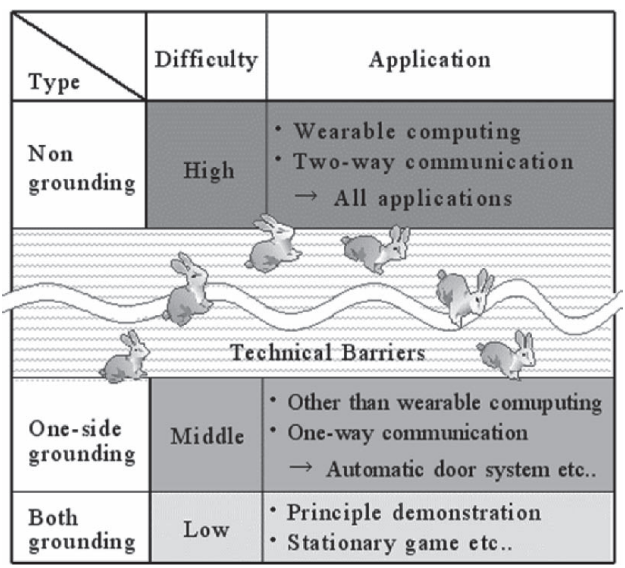

Fig. 9 Technical degree of difficulty
示す ${ }^{8)}$ 。特殊な電界センシング素子が必要となることから 「非接地型」と「部分接地型」の間には大きな技術障壁が存 在する。人体通信用の電界センシング素子には, 検出感度 だけでなく製造コストや信頼性が要求されることから，人 体通信技術が世界で初めて発表された 1995 年以来，MITを 含めて人体通信技術の研究を中止した研究者は, 殆どの場 合この障壁を越えられずに挫折しているようである。しか しながら, 最も難度の高い「非接地型人体通信」を実現で きると, 当初 MIT の研究チームが目指した双方向人体通信 によるウェアラブルコンピューティングが実現でき，電界 式人体通信技術が医療やセキュリティ，交通系や自動販売 機の料金決済システム，各種アミューズメントなど，考え 得る全ての分野のアプリケーションに適用できる可能性が 広がる。

本章においては，これまでビジネス上の秘密として明ら かにされることがなかった，電圧式人体通信技術における 接地パターンによる難易度の分類について，筆者の人体通 信研究を通じて得られた知見に基づく等価回路を用いて解 説した。

\section{3. 人体通信ガジェット}

\section{1 受信ガジェット $(\mathrm{Rx})$}

前章までに，電圧式人体通信技術の萌芽期から草創期に おける研究の歴史と，電圧式人体通信技術が実はさらに三 種類に分類されることを述べた。本章においては筆者が開 発した最新の人体通信ガジェットを紹介する。

Fig. 10 に示すのが，電圧式人体通信の受信ガジェット (Rx) である。このガジェットは，006P の乾電池一本で動作する $100 \% \mathrm{ASK}$ 方式の人体通信受装置で，非接地型人体通信を 構成することを目的に開発した。回路の動作電圧は $3 \mathrm{~V}$, 装置中央左側に実装されている 18 ピン DIP サイズの素子 が，筆者の開発した DCC-RS (Dispersion Capacitive Coupling Regenerative-circuit Sensor) である。この電界センサは，人 体を伝わる微弱な信号電界を特殊な方式で増幅する機能を 持つが，センサについての詳細な解説は別稿に譲る。この

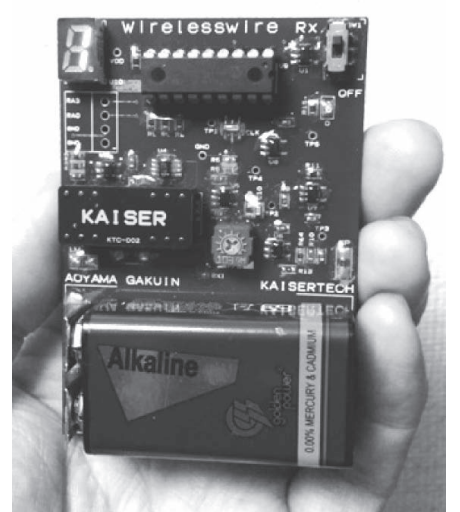

Fig. 10 Receiver gadget 


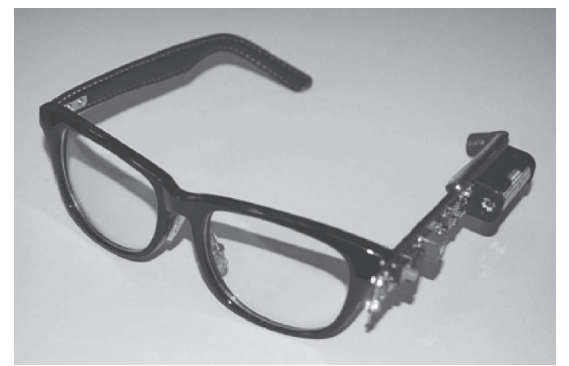

Fig. 11-1 Transmitter gadget (Glass type)

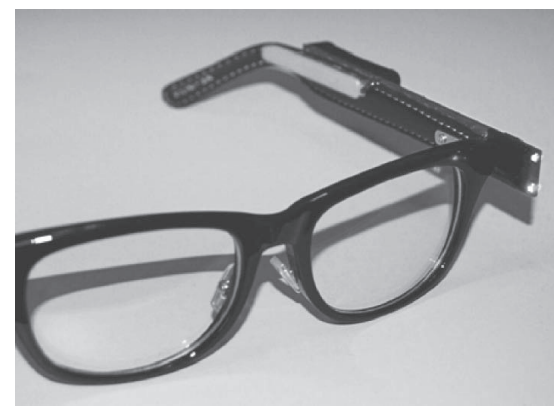

Fig. 11-2 Transmitter gadget (Glass type)

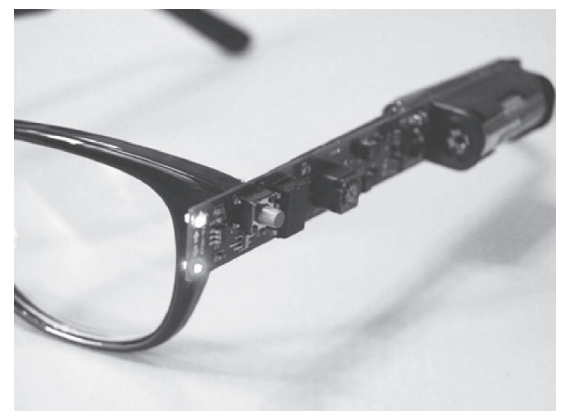

Fig. 11-3 Transmitter gadget (Glass type)

電界センサの開発によって，筆者は Fig. 9 中に示した技術 障壁をクリアした。

\section{2 眼鏡型送信ガジェット (Tx)}

Fig. 11-1〜11-3 に示すのが, 眼鏡型の人体通信送信ガ ジェット (Tx) である。通信方式は 100\%ASK 方式で, 搬送 波周波数は $1.5 \mathrm{MHz}$ である。送信電極から発生する電圧は 約 $3 \mathrm{~V}$ で, このガジェットも非接地型人体通信を構成する ことを目的に開発した。眼鏡の左側フレームに電池と回路 基板が実装されており，フレーム内側には人体に電圧を印 加するための送信電極が設けてある (Fig. 11-3)。送信電極 はラバーで被覆されており，金属面は人体に接触しない構 造となっている。電極面積は $4 \mathrm{~mm} \times 48 \mathrm{~mm}$ で, その值は 搬送波周波数や電極と人体間の距離など, 複数のパラメー 夕を独自の計算式に入力することで得られる。眼鏡右側の フレームに受信回路を取り付けることで, 双方向人体通信 ガジェットを実現できる。

3.3 指輪型送信ガジェット (Tx)

Fig. 12-1 と Fig. 12-2 に示すのが, 指輪型の人体通信送信ガ

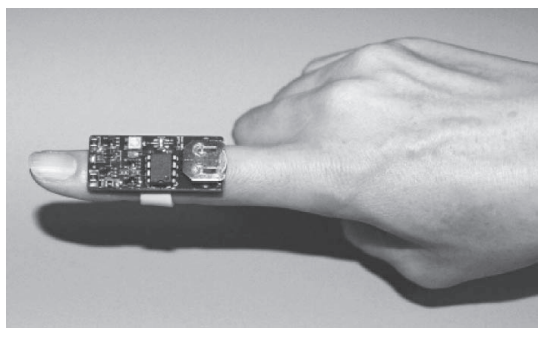

Fig. 12-1 Transmitter gadget (Ring type)

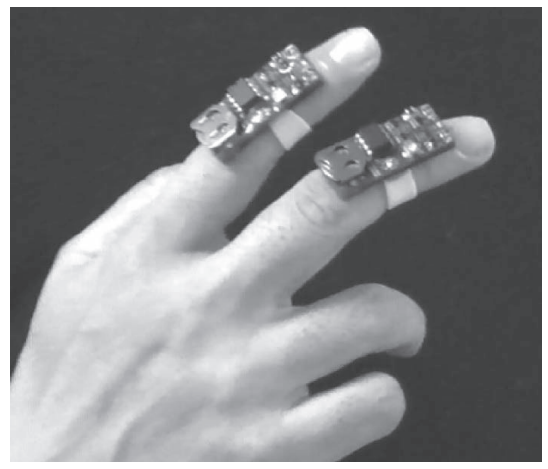

Fig. 12-2 Transmitter gadget (Ring type)

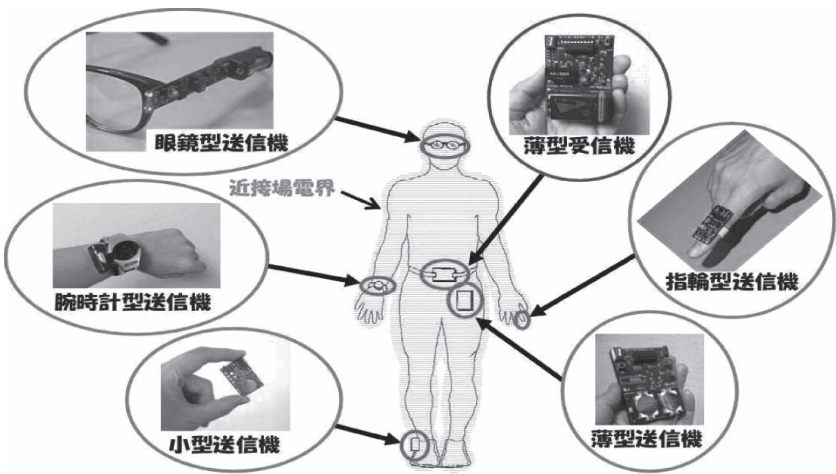

Fig. 13 The other gadgets

ジェット $(\mathrm{Tx})$ である。通信方式は眼鏡型と同様に 100\%ASK 方式で，搬送波周波数も $1.5 \mathrm{MHz}$ である。送信電極から発

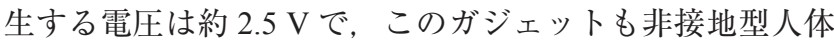
通信を構成することを目的に開発した。電子部品が実装さ れている回路基板の裏側に人体に電圧を印加するための送 信電極が設けてある。指先から人体を経由して, Fig. 10 の 受信ガジェットまでデータを伝送できる。このガジェット を応用すると, 次世代の人体通信式ポインティング・デバ イスやバーチャル・キーボードを構成できる。

\section{4 その他のガジェット}

筆者は，前述した眼鏡型や指輪型の他に送信用として， 腕時計型，小型 $(30 \mathrm{~mm} \times 40 \mathrm{~mm})$ などのガジェットなども 開発しており，その概略を Fig. 13 として示す。なお，これ らのガジェットは実際に動作することから，実際のアプリ ケーションへの適用も可能である。 


\section{4. むすび}

本稿前半では，これまでビジネス上の秘密として明らか にされることのなかった，電圧式人体通信における接地パ ターンによる技術難度の分類について, 筆者の研究を通じ て得られた知見に基づく等価回路を用いて解説した。さら に, 非接地型人体通信を実現するためには, 特殊な電界セ ンシング技術が必要であることを述べた。

また，後半では，筆者が近年開発した人体通信用ガジェッ トについて紹介し，その概略について解説した。今回は紙 面の都合で, 電界センシング素子や電極設計の詳細など, 電圧式人体通信技術の核心部について述べることは叶わな かったが，今後機会があれば是非発表したいと考えている。

\section{謝 辞}

人体通信技術の研究を進める上で日頃より助言頂く，青 山学院大学理工学部情報テクノロジー学科, 佐久田博司教 授に感謝する。人体通信と感性工学の融合について議論頂 いた, 資生堂化粧品基礎研究センター, 川副智行博士に感 謝する。

(2015.7.13- 受理)

\section{文献}

1) T. G. Zimmerman: "Personal Area Networks (PAN): Near-field Intra-body Communication," Thesis of the Massachusetts Institute of Technology, September 1995
2）福本雅朗, 外村佳伸：“ウェアラブル・コンピュータの世 界,”信学技報, IN 98-9, CS98-9, MVE98-9, pp. 57-63, 1998

3) 加藤康男, 品川 満：“EOS 技術を用いたデジタルオシロス コープ,”電子情報通信学会総合大会講演論文集, 1997 年, エレクトロニクス (2), p. 152, 1997

4) 佐々木愛一郎, 品川 満, 落合克幸: “人体通信用電気光学 センサ,”電子情報通信学会総合大会講演論文集，B-5-177, p. 626,2005

5）加藤康男，秋岡 幸，三林浩二：“ユビキタス人体通信によ る脈拍計測，”信学技報，VE2005-37, pp. 61-64, 2005

6) http://www.iri-tokyo.jp/joho/kohoshi/archives/tokyo21/ documents/tcpdf0601.pdf, p. 14

7) http://www.itmedia.co.jp/mobile/articles/0710/02/news098. $\mathrm{html}$

8）加藤康男，佐久田博司：“電界式人体通信の分類と自動車 への適用に関する一考察, ”自動車技術会, 自動車技術会論 文集，Vol. 44, No. 5, pp. 1315-1320, 2013

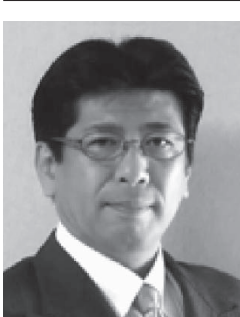

加藤康男（かとう やすお）

1987 年 東海大学工学部通信工学科卒業。同年 NEC 通信システム入社。1 994 2002 年 NTT グループ 企業 (NTT-AT, NEL) 在籍。2003 年 (株) カイザー テクノロジー代表取締役。2006 年 東京医科歯科 大学大学院医歯学総合研究科博士前期課程修了。 2014 年 青山学院大学大学院理工学研究科博士後 期課程修了。博士 (工学)。2015 年より青山学院 大学客員教員。現在に至る。 